\title{
PREVOTELLA INTERMEDIA AND PORPHYROMONAS GINGIVALIS ISOLATED FROM OSSEOINTEGRATED DENTAL IMPLANTS: COLONIZATION AND ANTIMICROBIAL SUSCEPTIBILITY
}

\author{
Eduardo Augusto Pfau; Mario Julio Avila-Campos* \\ Laboratório de Anaeróbios, Departamento de Microbiologia, Instituto de Ciências Biomédicas, Universidade de São Paulo, \\ São Paulo, SP, Brasil.
}

Submitted: November 23, 2004; Returned to authors for corrections: July 25, 2005; Approved: August 10, 2005

\begin{abstract}
The colonization and antimicrobial susceptibility of $P$. intermedia and $P$. gingivalis isolated from peri-implant and gingival sulcus samples were determined. Samples were collected from 30 patients submitted to implant in three different times: at the moment of the surgery, 20 and 60 days after the implant installation. Organisms were identified by using a biochemical tests or API 32-A kit and by PCR. The antimicrobial susceptibility was determined by using an agar dilution method. Nineteen $P$. intermedia ( 4 from peri-implant sites and 15 from gingival sulcus), and only seven $P$. gingivalis from gingival sulcus were isolated. Organisms were detected by PCR from seven peri-implant and 32 gingival samples. Bacteria were susceptible to the used antibiotics except to azithromycin with $65 \%$ of resistance for P. intermedia strains. Both tested species were susceptible to cadmium, nickel and palladium, and showed different resistance rates to titanium, aluminum and mercuric chloride. Most of $P$. intermedia strains were resistant to lead, silver, copper, titanium, zinc, aluminum and mercuric chloride. Bacteria colonized implants after 60 days of surgery and PCR may be used as a tool for bacterial detection in implantology.
\end{abstract}

Key words: Porphyromonas gingivalis, Prevotella intermedia, implants, antimicrobial susceptibility

\section{INTRODUCTION}

Dental microbial biofilm has an important role in the etiology of the periodontal diseases and peri-implantitis, and it has been estimated that approximately 415 bacterial species are localized in the subgingival plaque $(5,16)$. Species related to periodontal infections, such as Actinobacillus actinomycetemcomitans, Fusobacterium nucleatum, Tannerella forsythensis (Bacteroides forsythus), Porphyromonas gingivalis, Prevotella intermedia and spirochetes have also been identified from symptomatic infected implants $(11,15)$. In contrast, successful implants or healthy sites harbor a high percentage of Streptococcus spp., Actinomyces spp. and Capnocytophaga ochracea.

Dental implants have several designs and contain different materials such as pure titanium, alloys of titanium containing aluminum and vanadium, alloys of cobalt and chromium, aluminum oxide, and gold (10).

Bacterial infection is the main reason of failing implant after osseointegration, but it can also happen due to the used installation techniques or excessive oclusal force (9). However, because infection is a major barrier to the long-term function of implants, the survey of the specific microbiota around healthy and failing implants is important (17). It is known that a high prevalence of putative periodontopathogens in the pockets around dental implants of periodontal patients should indicate an increased risk of infection (9) and Prevotella spp. and Porphyromonas spp. are the most often isolated.

The molecular techniques for detection and identification of periodontopathogens represent an option for the microbiological control in implantology. A polymerase chain reaction (PCR) has

*Corresponding Author. Mailing address: Laboratório de Anaeróbios, Departamento de Microbiologia, ICB II, USP. Av. Prof. Lineu Prestes, 1374, Cidade Universitária. 05508-900, São Paulo, SP, Brasil. Tel.: (+5511) 3091-7344, Fax: (+5511) 3091-7354. E-mail: mariojac@usp.br 
been used for the direct detection of periodontal pathogens from subgingival clinical samples (4). However, detection of periodontal organisms in Brazilian dentistry is still not a routine.

Studies have shown an increase of resistance in Prevotella spp. and Porphyromonas spp. Resistant to several antibiotics, particularly, $\beta$-lactams, erythromycin, clindamycin, metronidazole, and tetracycline $(1,8)$. Moreover, many metals and alloys used as dental materials express an antibacterial effect mediated by the release and dissolution of the metal ions, but the metal antibacterial effect depends on the metal ions release interfering with the bacterial metabolism (7).

Considering the participation of black-pigmented gramnegative strict anaerobic rods in the different oral infectious processes, and because little information is known about the interaction of different metals from implants on specific oral organisms, the isolation and identification of Prevotella and Porphyromonas species from osseointegrated implants, in three different times, and their antimicrobial susceptibility were evaluated in this study.

\section{MATERIALS AND METHODS}

\section{Patients}

Thirty partially edentulous adult patients (14 male and 16 female) aged 35 - 60 years old (mean age 45.8 years) without clinical signs of periodontal disease and with at least three healthy teeth in the dental arch to place the implants were selected. Patients were previously submitted to the anamnesis and appropriate clinical exams such as radiographies, computerized tomographies and blood counts. None patient showed pathologies or disorders against the indicated implant installation surgery and they were not using antibiotics during the three months prior to the surgery. Moreover, patients were not in periodontal treatment.

At the moment of implant placement, a prophylaxis using dental cream and dental thread in all remaining teeth, as well as, mouthfuls with chlorhexidine digluconate solution $(0.12 \%)$ for 1 minute was performed. Patients received Branemark implants by one-step operative technique according to Bernard et al. (6).

\section{Bacteriological examination}

Implanted and gingival (control) sites were isolated with cotton rolls and supragingival plaque was removed by using sterile cotton pellets. Subgingival plaque samples from periimplant and gingival sulci (healthy adjacent teeth) were collected at three different clinical times. The first sample was collected at the moment of the surgery, the second sample collected from 25 to 30 days after the implant installation and the third sample was taken 60 days after surgery. Clinical samples were obtained by using three sterilized paper points (No. 40, Endpoints Ind. Ltd., Rio de Janeiro, RJ, Brazil), inserted to the depth apical site from peri-implant or gingival sulci, and left in place for 60 seconds (3). The paper points were transferred to $3.5 \mathrm{~mL}$ of prereduced
VMGA III (12) and aliquots of $0.1 \mathrm{~mL}$ of diluted samples were inoculated, in duplicate, onto blood brucella agar supplemented with $1 \mu \mathrm{g} / \mathrm{mL}$ menadione, $5 \mu \mathrm{g} / \mathrm{mL}$ hemine and $40 \mu \mathrm{g} / \mathrm{mL}$ kanamycin, and incubated in jars containing $90 \% \mathrm{~N}_{2}$ and $10 \%$ $\mathrm{CO}_{2}$, at $37^{\circ} \mathrm{C}$, for 10 days.

Black-pigmented colonies were characterized according to the colony and cellular morphologies, Gram-stain and fluorescence to ultra-violet light, and identified by conventional biochemical tests or by using a RAPID 32-A identification kit (bioMérieux, São Paulo, SP, Brazil). Moreover, a bacterial identification by using a PCR technique was performed. All the isolated strains were stored at $-80^{\circ} \mathrm{C}$ and lyophilized.

\section{PCR amplification}

DNA extraction. From each collected sample in VMGA III, $300 \mu \mathrm{L}$ were mixed with $300 \mu \mathrm{L}$ of sterilized ultra-pure water Milli-Q, and three-times washed (10,000 $g, 5$ minutes). Pellet was suspended in $300 \mu \mathrm{L}$ of water, homogenized and boiled for 10 minutes. Finally, samples were centrifuged $(14,000 \mathrm{~g}, 10$ minutes) and the supernatant (DNA) was used as template.

DNA amplification. Amplifications were performed using specific primer pairs according to Ashimoto et al. (2). Primers for $P$. intermedia were: 5'-TTT GTT GGG GAG TAAAGC GGG$3^{\prime}$ and $5^{\prime}$ - TCA ACA TCT CTG TAT CCT GCG T - 3', and for $P$. gingivalis: 5'- AGG CAG CTT GCC ATA CTG CG - 3' and 5'ACT GTT AGC AAC TAC CGA TGT - 3'. DNA amplification was performed in a final volume of $25 \mu \mathrm{L}$, containing $2.5 \mu \mathrm{L}$ (10 X PCR buffer), $1.25 \mu \mathrm{L}$ of $\mathrm{MgCl}_{2}(50 \mathrm{mM}), 1.0 \mu \mathrm{L}$ of dNTP mixture $(0.2 \mathrm{mM}), 1.0 \mu \mathrm{L}$ of each primer $(0.4 \mu \mathrm{M}), 0.25 \mu \mathrm{L}$ of Taq DNA polymerase $(0.5 \mathrm{U}), 8 \mu \mathrm{L}$ of water and $10 \mu \mathrm{L}$ of template. Amplifications were performed in a termocycler (Perkin Elmer, Gene Ampl PCR System 9700), programmed for 1 cycle of $94^{\circ} \mathrm{C}$ (5 minutes); 30 cycles of $94^{\circ} \mathrm{C}$ ( 30 seconds), $55^{\circ} \mathrm{C}$ or $60^{\circ} \mathrm{C}$ according to each primer pairs ( 30 seconds), $72^{\circ} \mathrm{C}$ (30 seconds); 1 cycle of $72^{\circ} \mathrm{C}$ ( 5 minutes). PCR products were analyzed by $1 \%$ agarose gel electrophoresis at $70 \mathrm{~V}$, for 2.5 hours. Gel was stained with $0.5 \mu \mathrm{g} / \mathrm{mL}$ ethidium bromide and photographed with a Digital Kodak Science System-DC-120. 1-kb DNA ladder (Invitrogen) was used as a molecular weight marker.

\section{Antimicrobial susceptibility testing}

Antibiotic and metal susceptibilities were performed by using an agar dilution method as recommended by the NCCLS (1997) in Wilkins-Chalgren agar with antibiotic concentrations ranging from 0.25 to $512 \mu \mathrm{g} / \mathrm{mL}$, and metal concentrations ranging from $0.01 \mathrm{M}$ to $0.0001 \mathrm{M}$. The antibiotics were as follows: amoxicillin, ampicillin, clindamycin (Luper Ind. Farm. Ltd., SP, Brazil.), azithromycin (Pfizer Ind. Farm. Ltd., SP, Brazil), amoxicillin + clavulanic acid (Smithkline Beecham Ltd., RJ., Brazil), chloramphenicol (Prodotti Lab. Farm. Ltd., SP, Brazil), erythromycin and tetracycline (Extratus Farm., Pr, Brazil), 
metronidazole (Alquimia Farm., SP, Brazil), and penicillin V (Wyeth-Whitehall Ltd., SP, Brazil). The metals were as follows: lead chloride $\left(9 \mathrm{PbCl}_{2}\right)$ and cadmium sulfate $\left(3 \mathrm{CdSO}_{4} .8 \mathrm{H}_{2} \mathrm{O}\right)$ (Vetec Ltd., RJ, Brazil), silver nitrate $\left(\mathrm{AgNO}_{3}\right)$, copper sulfate $\left(\mathrm{CuSO}_{4}\right)$, nickel sulfate $\left(\mathrm{NiSO}_{4} \cdot 6 \mathrm{H}_{2} \mathrm{O}\right)$, titanium dioxide $\left(\mathrm{TiO}_{2}\right)$, zinc sulfate $\left(\mathrm{ZnSO}_{4} \cdot 7 . \mathrm{H}_{2} \mathrm{O}\right)$, palladium chloride $\left(\mathrm{PdCl}_{2}\right)$, potassium aluminum sulfate [AlK $\left(\mathrm{SO}_{4}\right)_{2} .12 \mathrm{H}_{2} \mathrm{O}$ ], and mercuric chloride $\left(\mathrm{HgCl}_{2}\right)$ (Labsynth Prod. Lab. Ltd., SP, Brazil). Inocula of $10^{5} \mathrm{cfu}$ were delivered for a Steers replicator. The glass Petri dishes were incubated in anaerobiosis, $37^{\circ} \mathrm{C}$ for 72 hours. The minimal inhibitory concentration (MIC) was defined as the lowest concentration of each agent resulting in no growth or one discrete colony. Reference strains $P$. intermedia ATCC 25611 and $P$. gingivalis ATCC 33277 were included as controls in each test run. The used breakpoints for antibiotics were as recommended by NCCLS (14) and for metals was $0.001 \mathrm{M}$ in accordance with Riley and Mee (18).

\section{Statistical analyses}

A statistical analyses using a Chi-square test was performed.

\section{RESULTS}

A total of 26 isolates belonged to $19 P$. intermedia and $7 P$. gingivalis was recovered from peri-implant and gingival samples. From 73 peri-implant samples, only four $(5.48 \%)$ samples harbored $4 P$. intermedia strains. No $P$. gingivalis strain was isolated. Moreover, from 73 gingival samples, 9 (12.33\%) harbored only 15 P. intermedia strains and one (1.37\%) sample harbored $7 P$. gingivalis strains.

Organisms were detected by PCR in seven $(9.59 \%)$ periimplant and in $32(43.84 \%)$ gingival samples. A comparative detection of $P$. intermedia and $P$. gingivalis using culture and PCR in different collection times is showed in Table 1. Bacterial detection by PCR in the different collection times for gingival samples was more effective than by culture $(P<0.05)$. However, no statistical differences were observed in the bacterial detection from peri-implant samples by using both methods $(P>0.05)$. Black-pigmented anaerobic rods were isolated and identified at the $3^{\text {rd }}$ time of the collection (60 days after the implant installation) by culture and PCR methods. Although, these organisms were also isolated and identified from healthy sites in all the collection times by using both methods.

A high resistance rate to azithromycin (65\%) was only observed for $P$. intermedia. However, $P$. gingivalis strains were susceptible to this drug. Moreover, no organism showed resistance to other antibiotics (data not shown). On the other hand, $P$. intermedia strains showed resistance rates to lead (35\%), silver (50\%), copper (45\%), titanium (60\%), zinc (25\%), aluminum (85\%) and mercuric chloride (35\%), and $P$. gingivalis strains were resistant to titanium, aluminum and mercuric chloride (12.5\%) (Table 2).

\section{DISCUSSION}

Prevotella spp. and Porphyromonas spp. are strictly anaerobic organisms and commonly isolated from human oral and extra-oral infections (11). Studies have showed that presence of $P$. intermedia and $P$. gingivalis has an important role for unsuccessful of dental implant $(13,19)$. In this study, the occurrence of $P$. intermedia and $P$. gingivalis as colonizers of osseointegrated implants and healthy gingival sites of the adjacent to implants was evaluated.

As expected $P$. intermedia and $P$. gingivalis were not observed in the two first collection times but they were observed after 60 days after the implant installation (Table 1). Certainly, these organisms colonizing the installed implants were belonged to subgingival biofilm. In Brazil, studies about the presence of black-pigmented gram-negative strict anaerobic rods such as $P$. intermedia and $P$. gingivalis in patients with dental implants have not been observed. Moreover, microbiological data regarding the role of those organisms plays in the success or unsuccessful of implants and for choosing the best treatment for peri-implantitis is needed.

In Brazil the isolation and identification of anaerobic organisms in dental laboratories or periodontology and implantology clinics are not routine procedures. On the other hand, several methods for the bacterial identification and detection from subgingival plaque have been used.

The PCR detection for these organisms from collected samples was better than culture method $(P<0.05)$. Therefore, it is suggested that the PCR may be used to help avoiding the hard and time-consuming process of purification of black-pigmented colonies before employing any identification methods.

$P$. intermedia and $P$. gingivalis are usually resistant to antiseptics and antibiotics. However, antibiotics such as

Table 1. Detection of black-pigmented gram-negative strict anaerobic rods from peri-implant tissue and healthy tissue, adjacent to the implant, in different times of the collection, by using a culture and PCR methods.

\begin{tabular}{ccccccc}
\hline & \multicolumn{4}{c}{$\mathrm{N}^{\mathrm{o}}$ and (\%) of positive samples } \\
Clinical & \multicolumn{4}{c}{ in different times of collection } \\
\cline { 2 - 7 } Samples & \multicolumn{4}{c}{ Culture } \\
\cline { 2 - 7 }$($ No.) & $1^{\text {st }}$ & $2^{\text {nd }}$ & $3^{\text {rd }}$ & $1^{\text {st }}$ & $2^{\text {nd }}$ & $3^{\text {rd }}$ \\
\hline Implant (73) & 0 & 0 & $4(5.48)$ & 0 & 0 & $7(9.59)$ \\
Tooth (73) & $4(5.48)$ & $2(2.74)$ & $4(5.48)$ & $12(16.4)$ & $8(10.9)$ & $12(16.4)$ \\
\hline
\end{tabular}

$1^{\text {st }}$ time: at the moment of the implant installation; $2^{\text {nd }}$ time: 20 days after the implant installation; $3^{\text {rd }}$ time: 60 days after the implant installation. 
Table 2. Metal activity for $P$. intermedia and $P$. gingivalis strains recovered from healthy peri-implant and healthy tissues adjacent to the implant.

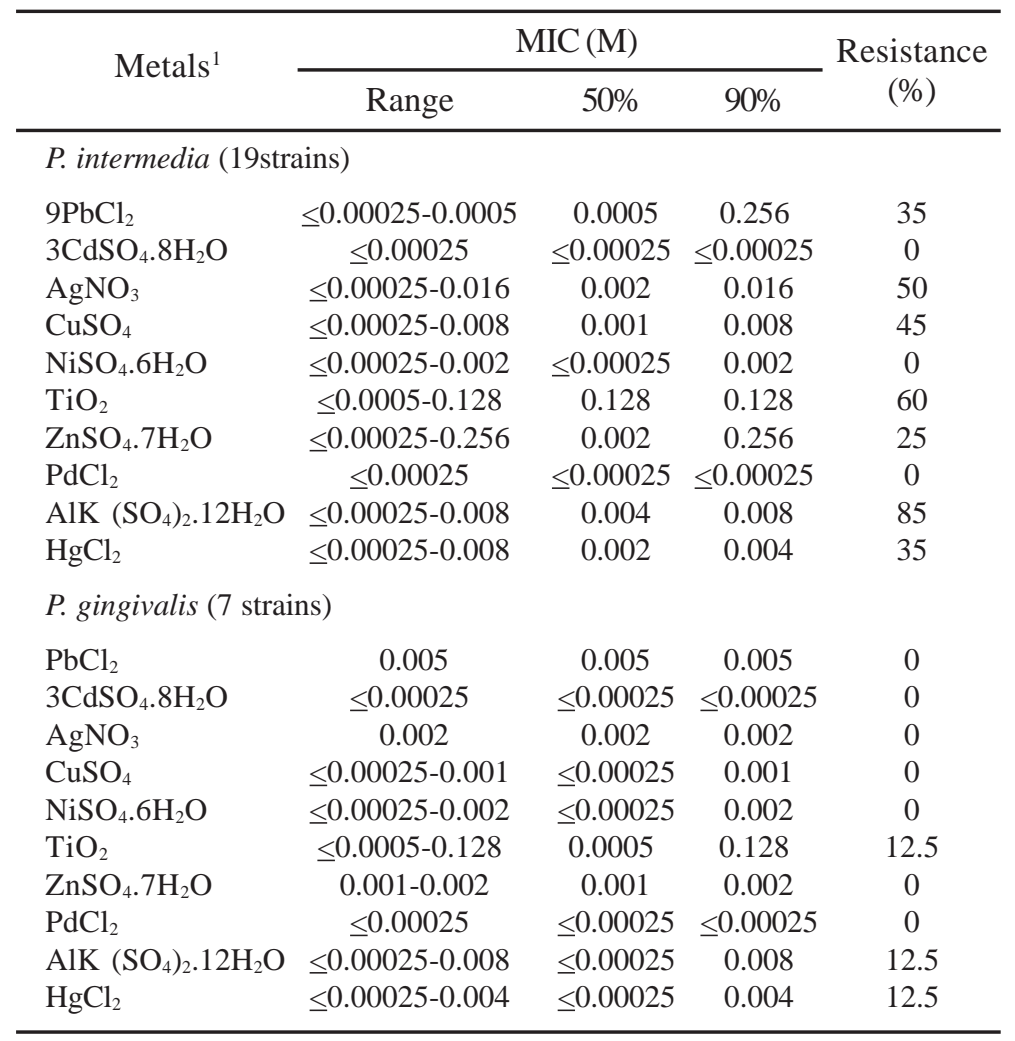

Breakpoint used for all metals was $0.001 \mathrm{M}$.

${ }^{1}\left(9 \mathrm{PbCl}_{2}\right)$ lead chloride; $\left(3 \mathrm{CdSO}_{4} .8 \mathrm{H}_{2} \mathrm{O}\right)$ cadmium sulfate; $\left(\mathrm{AgNO}_{3}\right)$ silver nitrate; $\left(\mathrm{CuSO}_{4}\right)$ copper sulfate; $\left(\mathrm{NiSO}_{4} \cdot 6 \mathrm{H}_{2} \mathrm{O}\right)$ nickel sulfate; $\left(\mathrm{TiO}_{2}\right)$ titanium dioxide; $\left(\mathrm{ZnSO}_{4} .7 \mathrm{H}_{2} \mathrm{O}\right)$ zinc sulfate; $\left(\mathrm{PdCl}_{2}\right)$ palladium chloride; [AlK $\left(\mathrm{SO}_{4}\right)_{2} .12 \mathrm{H}_{2} \mathrm{O}$ ] potassium aluminum sulfate; $\left(\mathrm{HgCl}_{2}\right)$ mercuric chloride.

metronidazole, azithromycin and $\beta$-lactam antibiotics plus $\beta$ lactamase inhibitors, are still generally active against Prevotella and Porphyromonas species (1). In our study, both the tested microorganisms were susceptible to all the used antibiotics, except to azithromycin with $65 \%$ of resistance, only for $P$. intermedia isolates.

The resident oral microbiota is constantly exposed to antimicrobial agents, including heavy metals, as observed in dental prosthesis, restorations, creams, mouth rinses and implants. However, the action mechanisms of several chemical agents including the metals on microorganisms have been studied, but their real inhibitory action remains still unclear (10). Moreover, metals can act as oxidant of important enzymes and proteins of the bacterial metabolism (18).

Recent studies have showed a selective activity of silver nitrate, gold, titanium and cobalt against $P$. gingivalis, $P$. intermedia, and A. viscosus (10). In this study, titanium and aluminum showed a poor activity against the tested organisms (Table 2).

In conclusion, our data suggest that $P$. intermedia and $P$. gingivalis species were able to colonize the peri-implant sites, three months after the implants exposition to oral environment and it is also suggested a periodic evaluation of the antimicrobial susceptibility to antibiotics and heavy metals. Moreover, a bacterial molecular detection could represent a new tool for bacterial detection in implantology.

\section{ACKNOWLEDGMENTS}

The authors thank Dr Katya Moreira for collecting the clinical samples and Mrs Zulmira Alves de Souza for her technical support. This study was granted for Fundação de Amparo à Pesquisa do Estado de São Paulo (FAPESP) Proc. No. 00/09742-0.

\section{RESUMO \\ Prevotella intermedia e Porphyromonas gingivalis isolados de implantes osseointegrados: colonização e susceptibilidade a antimicrobianos}

Neste estudo foram avaliadas a colonização e a susceptibilidade a antimicrobianos de $P$. intermedia e $P$. gingivalis isolados de amostras de sulcus gengivais e peri-implantares. As amostras foram coletadas de 30 pacientes submetidos a implantes, em três tempos diferentes: no momento da cirurgia, 20 e 60 dias após a instalação do implante. Os organismos foram identificados por testes bioquímicos ou por kit comercial API 32-A e por PCR. A susceptibilidade antimicrobiana foi determinada usando-se o método de diluição em ágar. Foram isolados dezenove $P$. intermedia (quatro de periimplantites e 15 de sulco gengival) e somente sete $P$. gingivalis de sulco gengival. Pelo PCR os organismos foram detectados de sete amostras sete peri-implantares e de 32 gengivais. As bactérias foram susceptíveis aos antibióticos usados exceto para azitromicina com $65 \%$ de resistência para $P$. intermedia. As espécies avaliadas foram sensíveis para cádmio, níquel e paládio, e mostraram diferentes faixas de resistência para titânio, alumínio e bicloreto de mercúrio. A maioria de $P$. intermedia foi resistente para chumbo, prata, cobre, titânio, zinco, alumínio e bicloreto de mercúrio. As bactérias colonizaram implantes após 60 dias de cirurgia e PCR pode ser usado como ferramenta para a detecção bacteriana na implantodontia.

Palavras-chave: Porphyromonas gingivalis, Prevotella intermedia, implantes, susceptibilidade antimicrobiana 


\section{REFERENCES}

1. Andres, M.T.; Chung, W.O.; Roberts, M.C.; Fierro, J.F. Antimicrobial susceptibilities of Porphyromonas gingivalis, Prevotella intermedia, and Prevotella nigrescens spp. isolated in Spain. Antimicrob. Agents Chemother, 42, 3022-3023, 1998.

2. Ashimoto, A.; Chen, C.; Bakker, I.; Slots, J. Polymerase chain reaction detection of 8 putative periodontal pathogens in subgingival plaque of gingivitis and advanced periodontitis lesions. Oral Microbiol. Immunol., 11, 266-273, 1996.

3. Avila-Campos, M.J.; Farias, L.M.; Carvalho, M.A.R.; Damasceno, C.A.V.; Cisalpino, E.O.; Costa, J.E. Aspectos ecológicos de Actinobacillus actinomycetemcomitans: aislamiento y caracterización de cepas. Rev. Latino-amer. Microbiol., 30, 301-305, 1988.

4. Avila-Campos, M.J.; Velásquez-Meléndez, J.G. Identification of putative periodontal microorganisms from periodontal patients and healthy subjects. Rev. Inst. Med. Trop. São Paulo, 44, 1- 5, 2002.

5. Becker, W.; Becker, B.E.; Neuman, M.G.; Nyman, S. Clinical and microbiologic findings that may contribute to dental implant failure. Int. J. Oral Maxillofacial Implants., 5, 31-38, 1990.

6. Bernard, J.P.; Belser, U.C.; Martinet, J.P.; Borgis, S.A. Osseointegration of Branemark fixtures using a single-step operating technique. A preliminary prospective one-year study in the edentulous mandible. Clin. Oral Implants Res., 6, 122-129, 1995.

7. Berry, C.W.; Moore, T.J.; Safar, J.A.; Henry, C.A.; Wagner, M.J. Antibacterial activity of dental implant metals. Implant Dent., 1, 59-65, 1992.

8. Carrasco, E.; Martinez, M.; Calbacho, M.; Wilckens, M. In vitro activity of amoxicillin, tetracycline, azitromycin, ofloxacin and metronidazole against Porphyromonas gingivalis, Prevotella intermedia, and Fusobacterium nucleatum strains. Anaerobe, 5, 443-445, 1999.
9. Lee, K.H.; Maiden, M.F.J.; Tanner, A.C.R.; Weber, H.P. Microbiota of successful osseointegraded dental implants. J. Periodontol., 70, 131-138, 1999.

10. Leonhardt, A.; Dahlén, G. Effect of titanium on selected oral bacteria species in vitro. Europ J. Oral Sciences, 103, 382-387, 1995.

11. Mättö, J.; Asikainen, S.; Väisänen, P.; Finegold, S.; Jousimies-Somier, H. Role of Porphyromonas gingivalis, Prevotella intermedia, and Prevotella nigrescens in extra oral and some odontogenic infections. Clin. Infect. Dis., 25, 194-198, 1997.

12. Möller, A.J.R. Microbiological examination of root canals and periapical tissues of human teeth. Odontol. Tidsk., 74: 380, 1966.

13. Mombelli, A.; van Oosten, M.A.C.; Schurch, E.; Lang, N.P. The microbiota associated with successful or failing osseointegrated titanium implants. Oral Microbiol. Immunol., 2, 145-151, 1987.

14. National Committee for Clinical Laboratory Standard. Methods for antimicrobial susceptibility testing of anaerobic bacteria, $4^{\text {th }}$ ed., Approved Standard. NCCLS document M11-A4. National Committee for Clinical Laboratory Standards, Wayne, Pa., 1997.

15. Paster, B.J.; Boches, S.K.; Galvin, J.L.; Ericson, R.E.; Lau, C.N.; Levanos, V.A.; Sahasrabudhe, A.; Dewhirst, F.E. Bacterial diversity in human subgingival plaque. J. Bacteriol., 183, 3770-3783, 2001.

16. Piovano, S. Bacteriology of most frequent oral anaerobic infections. Anaerobe, 5, 221-227, 1999.

17. Poulet, P.P.; Duffaut, D.; Lodter, J.P.; Malet, N. Étude in vitro de la sensibilité aux antibiotiques des bactéries anaerobies strictes associées à la maladie paradontale. J. Paradontol. Implantol. Orale, 18, 251258, 1999.

18. Riley, T.V.; Mee, B.J. Susceptibility of Bacteroides spp. to heavy metals. Antimicrob. Agents Chemother, 22, 889-892, 1982.

19. Salcetti, J.M.; Moriartry, J.D.; Cooper, L.F.; Smith, F.W.; Collins, J.G.; Socransky, S.S.; Offenbacher, S. The clinical, microbial, and host response characteristics of the failing implant. Intern. J. Oral Maxillofacial Implants, 12, 32-42, 1997. 